\title{
KARAKTERISTIK PERMEN JELLY TIMUN SURI (Cucumis melo L.) DENGAN PENAMBAHAN SORBITOL DAN EKSTRAK KUNYIT (Curcuma domestika Val.)
}

\author{
(Characteristics of Cucumis melo L. Jelly Candies with the Addition of Sorbitol and \\ Curcuma domestika Val. Extract)
}

\author{
Merynda Indriyani Syafutri ${ }^{1 *}$, Eka Lidiasari ${ }^{1}$, dan Hendra Indawan ${ }^{1}$ \\ ${ }^{1 *}$ Alamat korespondensi: Program Studi Teknologi Hasil Pertanian, Jurusan Teknologi Pertanian, \\ Fakultas Pertanian, Universitas Sriwijaya, Indralaya; Tel: 0711-580664, Email: misyafutri@yahoo.com \\ 1 Program Studi Teknologi Hasil Pertanian, Jurusan Teknologi Pertanian, Fakultas Pertanian, \\ Universitas Sriwijaya, Indralaya.
}

\begin{abstract}
The objective of this research was to determine the chemical and organoleptic characteristics of Cucumis melo L. jelly candies with the addition of sorbitol and Curcuma domestika Val. extract. This research was conducted in the Chemical Laboratory of Agricultural, Department of Agricultural Technology, Agricultural Faculty, Sriwijaya University, Indralaya, from January 2010 to June 2010. This research used a Factorial Completely Randomized Design with two treatments and three replications for each treatment. S factor was the addition of sorbitol concentration (9\%, 16\% and 23\%) and $E$ was the concentration factor addition of Curcuma domestika Val. extract (5\%, 7\% and $9 \%$ ). The results showed that the addition of sorbitol concentration had significant effect on the water content, $\mathrm{pH}$, total sugar and antioxidant activity of Cucumis melo L. jelly candies. The addition of Curcuma domestika Val. extract had significant effect on the water content and antioxidant activity of Cucumis melo L. jelly candies. Interaction addition of sorbitol and Curcuma domestika Val. extract had significant effect on the antioxidant activity of jelly candies. $\mathrm{S}_{2} \mathrm{E}_{2}$ treatment (sorbitol $20 \%$ and $7.5 \%$ Curcuma domestika Val. extract) was the best treatment with chemical characteristics (water content 36.48\%, ash content 3.01\%, pH 5.03, total sugar $37.00 \%$ and the antioxidant activity $27.09 \%$ ), and sensory characteristics by scoring preferences (color 3.08, texture 2.88, odour 3.08 and taste 2.88).
\end{abstract}

Key words: Cucumis melo L, Curcuma domestika Val, Jelly candy.

\section{PENDAHULUAN}

Timun suri (Cucumis melo L.) merupakan salah satu jenis produk hasil pertanian yang banyak terdapat di daerah Sumatera Selatan. Timun suri juga mengandung sejumlah zat gizi yang baik bagi tubuh, seperti karbohidrat 2,09 $\mathrm{g}$, protein $1,26 \mathrm{~g}$, lemak $0,04 \mathrm{~g}$, serat $0,89 \mathrm{~g}$, air $96,32 \mathrm{~g}$, abu $2,90 \mathrm{~g}$, vitamin C $24,86 \mathrm{mg}$, kalium $1008 \mathrm{mg}$, kalsium $768 \mathrm{mg}$, dan posfor $422 \mathrm{mg}$ (Hayati et al, 2008). Selain itu, buah ini juga memiliki jenis dan rasa yang segar, flavor yang khas dan daging buah yang tebal.

Usaha diversifikasi dan pengolahan timun suri menjadi permen jelly diperkirakan mempunyai prospek yang cukup baik. Hal ini terjadi karena produk permen sudah banyak disukai oleh anak-anak, remaja maupun dewasa. Menurut Sura et al. (2009), dalam penelitian tentang karekteristik jelly timun suri (Cucumis melo L.) sebanyak $15 \%$, sukrosa $20 \%$, HFS $50 \%$ dan asam sitrat $0.2 \%$ secara sensoris memiliki tingkat kesukaan tertinggi dari perlakuan lain dan didapatkan karekteristik permen jelly timun suri yang baik.

Permen jelly merupakan produk confectionary yang dapat diolah dari berbagai macam variasi, baik warna, bahan baku, maupun flavor. Bahan utama yang umum digunakan dalam pembuatan permen jelly adalah gelatin yang berfungsi sebagai bahan pengental, gula sebagai pemanis dan asam organik sebagai bahan pengawet dan pemberi rasa asam pada produk. Fungsi utama penambahan gelatin dalam pembuatan permen jelly yaitu untuk meningkatkan elastisitas, konsistensi dan stabilitas produk (Jaswir, 2007).

Penggunaan jenis bahan pemanis pada pengolahan makanan sangat sering dilakukan. Bahan pemanis yang sering digunakan dalam pengolahan makanan, misalnya pada pembuatan permen jelly adalah jenis gula sukrosa. Seperti yang telah diketahui, sukrosa sebagai ba- 
han pemanis memiliki kandungan kalori yang cukup tinggi yaitu sebesar 400 kalori dalam 100 gram bahan.

Konsumsi makanan dan minuman dengan kandungan gula tinggi secara berlebihan dan tanpa diimbangi dengan asupan gizi lain dapat menimbulkan gangguan metabolisme dalam tubuh sehingga menyebabkan gangguan kesehatan (Usmiati \& Yuliani, 2004). Selain itu, konsumsi gula juga dapat mempangaruhi kerusakan pada gigi. Kondisi ini menjadikan penggunaan sukrosa atau yang lebih dikenal dengan gula sebagai bahan pemanis utama semakin tergeser. Jenis bahan pemanis yang alami atau pun pemanis buatan yang memberikan efek kesehatan sangat dibutuhkan dalam industri pengolahan makanan. Adapun jenis pemanis yang dapat digunakan pada pengolahan permen jelly adalah High Fructose Syrup (HFS) dan sorbitol.

HFS merupakan jenis bahan pemanis yang rendah kalori yang manisnya dua kali lebih manis daripada sukrosa. Penggunaan HFS dalam industri permen khususnya permen jelly, berperan dalam memperbaiki tekstur dan menjadikan penampakan produk permen jelly yang bening dan transparan (Balai Besar Litbang Pasca Panen, 2004).

Sorbitol adalah monosaccharide polyhydric alcohol dan hexitol yang banyak digunakan pada produk pasta gigi dan bahan makanan dan minuman (Anonim, 2008). Sorbitol memiliki efek pendingin dan memiliki beberapa keunggulan dibanding gula lainnya, yaitu rasanya cukup manis namun tidak merusak gigi. Sorbitol memiliki tingkat kemanisan cukup tinggi sekitar 50 sampai 70\% di bawah sukrosa, dan kandungan kalorinya yang rendah berkisar 2.6 $\mathrm{Kal} / \mathrm{g}$ (Badan Standar Nasional, 2004). Menurut Soeratri et al. (2005), sorbitol mempunyai kelebihan yaitu dapat mempertahankan kelembapan pada bahan makanan dan penggunaannya dalam pengolahan pada suhu tinggi tidak menyebabkan terjadinya reaksi pencoklatan (Maillard). Badan Pengawas Obat dan Makanan (2001) mengatur penggunaan sorbitol pada produk pangan yaitu berkisar antara 500 sampai dengan 200000 mg/kg produk.

Kualitas dari permen jelly timun suri tidak hanya ditentukan dari bahan baku yang digunakan, akan tetapi juga ditentukan oleh penampakan dari luar produk misalnya warna dari produk tersebut agar lebih disukai oleh masyarakat secara estetika. Penggunaan pewarna alami dalam pengolahan produk sangat dianjurkan agar dihasilkan produk yang sehat.
Salah satu jenis pewarna alami yang sering digunakan pada industri pengolahan makanan adalah kunyit.

Kunyit (Curcuma domestika Val) merupakan salah satu tanaman obat tradisional Indonesia, yang mengandung senyawa alami (kurkuminoid) yang memberi warna kuning pada kunyit. Menurut Winarto (2005), kurkuminoid merupakan salah satu senyawa fitokimia penting bagi tubuh sebagai antioksidan, antihepatotoksik, antiinflamasi dan antirematik. Penggunaan ekstrak kunyit pada pembuatan permen jelly timun suri diharapkan dapat memperbaiki warna dari produk yang dihasilkan, disamping memiliki kandungan senyawa fitokimia yang bersifat antioksidan dari kunyit dan bermanfaat bagi kesehatan tubuh.

Penelitian ini bertujuan untuk mempelalajari karakteristik kimia dan organoleptik permen jelly timun suri (Cucumis melo L.) dengan penambahan sorbitol dan ekstrak kunyit (Curcuma domestika Val).

\section{METODE}

\section{Tempat dan Waktu}

Penelitian ini dilakukan di Laboratorium Kimia Hasil Pertanian, Jurusan Teknologi Pertanian, Fakultas Pertanian, Universitas Sriwijaya, Indralaya dari bulan Januari sampai dengan Juni 2010.

\section{Alat dan Bahan}

Alat-alat yang digunakan dalam penelitian ini adalah: baskom, cetakan aluminium, Juice Exstrasion (Juicer), muffle furnace, pisau stainlees, pH-meter, refraktometer, saringan kelapa, spektrofotometer, timbangan analitik merek Adventur, kompor gas, lemari es, dan alat-alat gelas untuk analisa.

Bahan-bahan yang digunakan dalam penelitian ini adalah asam sitrat, beef gelatin, buah timun suri yang matang optimum (umur panen berkisar 2 bulan) ekstrak kunyit, HFS, sorbitol bubuk, dan bahan-bahan kimia untuk analisa.

\section{Cara Kerja}

Cara kerja dalam penelitian ini adalah cara kerja pembuatan permen jelly timun suri menurut Sura et al. (2009), yang telah dimodifikasi yaitu sebagai berikut: timun suri dipilih yang matangnya optimum (umur panen berkisar 2 bulan) dan teksturnya masih agak keras 
serta tidak rusak, dikupas dan dibuang biji serta kulitnya kemudian daging buah dipotong kecil-kecil lalu dihancurkan menggunakan juicer untuk mendapatkan sari buah.

Sari buah sebanyak $100 \mathrm{ml}$ dicampur dengan ekstrak kunyit murni sesuai dengan konsentrasi perlakuan dan diaduk sampai merata. Campuran sari buah dan ekstrak kunyit, dipanaskan pada suhu $40^{\circ} \mathrm{C}$ lalu ditambahkan asam sitrat $0.2 \%$, HFS $50 \%$, gelatin $15 \%$ (dari $100 \mathrm{ml}$ sari buah timun suri) dan sorbitol bubuk sesuai dengan konsentrasi perlakukan sambil dilakukan pengadukan selama pemanasan. Pemanasan dilanjutkan sampai suhu $100^{\circ} \mathrm{C}$ sampai tercapai kekentalan dan diangkat dari alat pemanasan. Cairan kental permen jelly langsung dituangkan ke cetakan alumunium persegi $(10 \mathrm{x}$ $10 \times 2 \mathrm{~cm}^{3}$ ), dan didinginkan/didiamkan pada suhu ruang $25-30^{\circ} \mathrm{C}$ selama \pm 1 jam. Setelah \pm 1 jam, permen jelly dimasukkan ke lemari pendingin dengan suhu $5^{\circ} \mathrm{C}$ selama 24 jam. Setelah dikeluarkan dari lemari pendingin, permen jelly dibiarkan pada suhu ruang $25-30^{\circ} \mathrm{C}$ selama \pm 1 jam. Dan dikeluarkan dari cetakan, kemudian. dilakukan analisa terhadap permen jelly yang dihasilkan.

\section{Parameter Pengamatan}

\section{Kadar Air}

Penentuan kadar air menggunakan metode AOAC (1995), sebagai berikut: cawan alumunium dibersihkan dan dipanaskan dalam oven selama 15 menit, setelah itu dimasukkan dalam desikator sampai dingin, lalu ditimbang. Permen jelly diambil $\pm 4 \mathrm{~g}$ dan dimasukkan ke dalam cawan, kemudian dimasukkan ke dalam oven $105^{\circ} \mathrm{C}$ sampai berat kering konstan. Sampel yang sudah kering dikeluarkan dari oven dan dimasukkan ke dalam desikator, setelah dingin ditimbang dengan neraca analitik.

$\%$ Kadar air (basis basah) $=\frac{g A-g K \times 100 \%}{g K}$

Keterangan:

gA = Berat sampel awal (gram)

$\mathrm{gK}=$ Berat sampel kering (gram)

\section{Kadar Abu}

Penentuan kadar abu menggunakan metode AOAC (1995) menggunakan Muffle furnace merek Sybron adalah sebagai berikut: cawan porselen dibersihkan dan dipanaskan dalam oven selama 15 menit, lalu dimasukkan desikator sampai dingin, kemudian ditimbang. Permen jelly ditimbang 2 g dan dimasukkan dalam cawan porselen, kemudian dipanaskan dengan menggunakan penagas listrik dalam lemari asam sampai asap pada sampel hilang dan warna sampel menjadi hitam. Sampel tersebut selanjutnya diabukan dengan cara dimasukkan ke dalam Muffle furnace dengan suhu $550^{\circ} \mathrm{C}$ sampai menjadi abu. Kemudian dimasukkan ke dalam oven selama 15 menit, setelah itu dimasukkan ke dalam desikator sampai dingin. Kemudian ditimbang.

$$
\text { \% Kadar abu (basis basah) }=\frac{b A}{b S} \times 100 \%
$$

Keterangan:

$\mathrm{gA}=$ Berat abu (gram)

$\mathrm{gK}=$ Berat sampel basah (gram)

\section{Uji $p H$}

Penentuan nilai $\mathrm{pH}$ menggunakan $\mathrm{pH}$ meter merek Autech (Sudarmadji et al., 1997), sebagai berikut : elektroda $\mathrm{pH}$ meter sebelum digunakan distandarisasi menggunakan larutan buffer. Kemudian dbersihkan menggunakan aquadest dan dikeringkan. Sampel permen jelly sebanyak $1 \mathrm{~g}$ kemudian dihancurkan dan ditambahkan aquadest sebanyak $5 \mathrm{ml}$, dikocok sampai homogen. Dicelupkan elektroda ke dalam sampel, dibiarkan elektroda sampai diperoleh pembacaan yang stabil. Nilai $\mathrm{pH}$ dapat langsung dibaca pada skala $\mathrm{pH}$ meter.

\section{Kadar Gula Total}

Penentuan kadar gula menggunakan Refraktometer merek Atago (Sudarmadji et al, 1997), sebagai berikut: sampel permen jelly sebanyak $1 \mathrm{~g}$ dihancurkan dan ditambahkan aquadest sebanyak $1 \mathrm{ml}$, kemudian dikocok sampai homogen. Larutan diteteskan di atas lensa Refraktometer sebanyak satu sendok teh. Nilai kadar gula sampel dapat langsung dibaca pada monitor Refraktometer.

\section{Uji Aktivitas Antioksidan}

Uji aktivitas antioksidan berdasarkan Joyeux et al. (1995) dengan menggunakan sistem larutan DPPH (diphenyl picril hydrazil hydrate) dengan cara kerja sebagai berikut: sampel permen jelly diambil $10 \mathrm{mg}$ dan dilarutkan dengan metanol $10 \mathrm{ml}$. Dari larutan di atas diambil $2 \mathrm{ml}$ lalu ditambahkan $4 \mathrm{ml}$ DPPH (1.9 mg DPPH ditambah $50 \mathrm{ml}$ metanol). Larutan dimasukkan ke dalam cuvet lalau ditera menggunakan Spektrofotometer (panjang gelombang $520 \mathrm{~nm}$ ) pada menit ke 0 dan menit ke 30. Hasil peneraan Spektofotometer pada menit ke 0 dan ke 30 dicatat, kemudian dihitung dengan rumus sebagai berikut :

\%Aktivitas Antioksidan $=\frac{\mathrm{P}_{0}-\mathrm{P}_{1}}{\mathrm{P}_{0}} \times 100 \%$ 
Keterangan :

$\mathrm{P}_{0}=$ Hasil penerapan Spektofotometer pada menit ke 0 $\mathrm{P}_{1}=$ Hasil penerapan Spektofotometer pada menit ke 1

\section{Uji Hedonik}

Penilaian terhadap warna, tekstur, aroma, dan rasa permen jelly dilakukan secara sensoris menggunakan metode uji hedonik (Soekarto, 1985). Pengujian dilakukan terhadap 25 orang panelis agak terlatih. Sampel diletakkan di atas piring dan diberi kode 3 digit secara acak. Panelis diminta untuk memberikan penilaian kesukaan dengan memberikan skor dalam skala sebagai berikut: $1=$ sangat tidak suka, 2 = tidak suka, $3=$ suka, dan $4=$ sangat suka.

\section{Rancangan Penelitian dan Analisis Data}

Rancangan penelitian yang digunakan ialah Rancangan Acak Lengkap (RAL) faktorial dengan dua faktor perlakuan yaitu konsentrasi sorbitol bubuk (S) yang terdiri dari 3 taraf (S1 $9 \%$, S2 16\%, S3 23\%) dan konsentrasi ekstrak kunyit (E) yang terdiri dari 3 taraf (E1 5\%, E2 7\%, E3 9\%), sehingga diperoleh 9 kombinasi perlakuan. Setiap kombinasi perlakuan akan diulang sebanyak 3 kali.

Semua komponen perlakuan diuji dengan analisis ragam (ANOVA) pada selang kepercayaan $95 \%(\alpha=0.05)$, kemudian dilanjutkan dengan uji lanjut BNJ (Beda Nyata Jujur). Uji hedonik terhadap warna, tekstur, aroma dan rasa dianalisis menggunakan FriedmanConover. Data yang diperoleh dianalisis dengan program Microsoft Office Excel 2003.

\section{HASIL DAN PEMBAHASAN}

\section{Kadar Air}

Hasil analisis menunjukkan bahwa kadar air permen jelly timun suri dengan penambahan sorbitol dan ekstrak kunyit berkisar antara
$34.18 \%$ sampai dengan $40.82 \%$. Kadar air permen jelly yang tertinggi $40.82 \%$ diperoleh dari perlakuan $\mathrm{S}_{3} \mathrm{E}_{3}$ (sorbitol $30 \%$ dan ekstrak kunyit $10 \%$ ), sedangkan kadar air terendah $34.18 \%$ dari perlakuan $\mathrm{S}_{1} \mathrm{E}_{1}$ yaitu sorbitol $10 \%$ dan ekstrak kunyit 5\%. Rerata kadar air permen jelly pada berbagai perlakuan disajikan pada Gambar 1.

Hasil analisis keragaman menunjukkan bahwa perlakuan konsentrasi sorbitol dan ekstrak kunyit berpengaruh nyata terhadap kadar air permen jelly timun suri, sedangkan perlakuan interaksi sorbitol dan ekstrak kunyit berpengaruh tidak nyata. Kadar air permen jelly yang terendah terdapat pada perlakuan $\mathrm{S}_{1}$ (sorbitol 9\%), yang menunjukkan bahwa air yang terikat dalam bahan semakin sedikit dan air yang diuapkan oleh panas semakin banyak, sehingga kadar airnya semakin rendah. Menurut Soeratri et al. (2004), sorbitol merupakan jenis gula alkohol yang memiliki kemampuan sebagai humektan atau dapat menstabilkan kadar air ini, sehingga dapat melindungi produk ini dari pemanasan dan menjaga kesegaran awal produk selama penyimpanan. Menurut Winarno (1997), sorbitol memiliki komposisi kimianya yang terdiri dari tiga atau lebih kelompok hidroksil. Gugus hidroksil berfungsi mengikat air bebas yang berada di luar dan membentuk ikatan hidrogen dengan air. Sehingga semakin tinggi kosentrasi sorbitol (23\%) dalam bahan maka semakin tinggi air yang akan terikat pada bahan dan menyebabkan semakin sedikit air yang akan diuapkan oleh panas sehingga kadar air dalam bahan menjadi tinggi.

Perlakuan kosentrasi ekstrak kunyit yang tinggi $(9 \%)$ akan meningkatkan volume air pada bahan sehingga menyebabkan kadar air menjadi tinggi karena air akan terikat dalam bahan oleh gugus hidroksil pada gula sorbitol. Kunyit merupakan jenis tanaman umbi-umbian yang memiliki kadar air dalam bentuk rimpang berkisar 11\% sampai 20\% (Sulaeman dan Katipana,

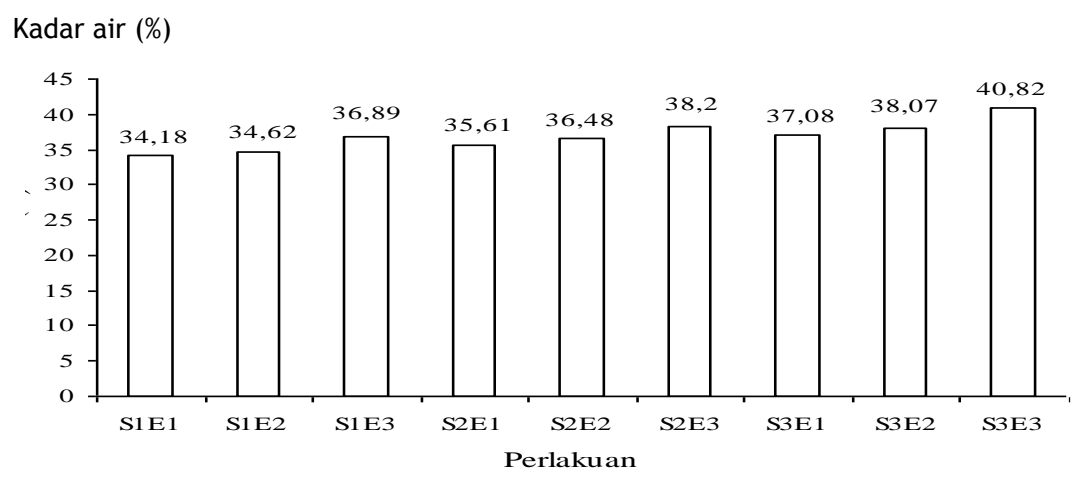

Gambar 1. Grafik rerata kadar air (\%) permen jelly timun suri 
1997). Kunyit yang digunakan sebagai bahan tambahan dalam pembuatan permen jelly timun suri ini adalah dalam bentuk ekstrak murni kunyit (cair).

\section{Kadar Abu}

Hasil pengukuran kadar abu permen jelly timun suri berkisar antara $2.80 \%$ sampai $3.13 \%$. Kadar abu tertinggi diperoleh dari hasil perlakuan $\mathrm{S}_{1} \mathrm{E}_{3}$ (sorbitol 9\% dan ekstrak kunyit 9\%) dengan nilai $3.13 \%$, sedangkan kadar abu terendah diperoleh dari perlakuan $\mathrm{S}_{3} \mathrm{E}_{1}$ (sorbitol $23 \%$ dan ekstrak kunyit 5\%) dengan nilai kadar abu 2,80\%. Grafik rerata kadar abu permen jelly timun suri dapat dilihat pada Gambar 2 .

Berdasarkan SNI 01-3547-1994, permen jelly memiliki standar kadar abu 3\%, hal ini menunjukkan bahwa kadar abu permen jelly timun suri yang dihasilkan telah memenuhi standar nasional permen jelly. Hasil analisis keragaman menunjukkan bahwa perlakuan konsentrasi penambahan sorbitol, ekstrak kunyit dan interaksi keduanya berpengaruh tidak nyata terhadap kadar abu permen jelly timun suri yang dihasilkan. Menurut Sudarmadji et al. (1997), kadar abu ada hubungannya dengan mineral suatu bahan dan penambahan bahan anorganik tambahan pada bahan tersebut akan meningkatkan kadar abu pada bahan tersebut.
Menurut Hayati et al. (2008), timun suri memiliki kandungan mineral yang terdiri fosfor $422 \mathrm{mg}$, kalium $1008 \mathrm{mg}$ dan kalsium $768 \mathrm{mg}$ serta kadar abu $2.902 \mathrm{~g}$ per $100 \mathrm{~g}$ berat bahan. Kunyit dalam bentuk rimpang segar memiliki kadar abu $6 \%$ sampai $7 \%$ yang terdiri dari kandungan mineral seperti kalsium, fosfor dan besi (Wahyuni et al, 2004).

$\mathrm{pH}$

$\mathrm{pH}$ merupakan derajat atau tingkat keasaman suatu larutan. Hasil pengamatan $\mathrm{pH}$ permen jelly timun suri berkisar antara 4.83 sampai 5.06. Nilai pH permen jelly tertinggi 5.06 yaitu pada perlakuan $\mathrm{S}_{3} \mathrm{E}_{3}$ (sorbitol $23 \%$ dan ekstrak kunyit $9 \%$ ), sedangkan nilai $\mathrm{pH}$ terkecil 4.83 yaitu pada perlakuan $\mathrm{S}_{1} \mathrm{E}_{1}$ (sorbitol 9\% dan ekstrak kunyit 5\%). Rerata pH permen jelly timun suri pada berbagai perlakuan dapat dilihat pada Gambar 3.

Hasil analisa keragaman nilai $\mathrm{pH}$ menunjukkan bahwa perlakuan konsentrasi sorbitol berpengaruh nyata terhadap nilai $\mathrm{pH}$ permen jelly timun suri yang dihasilkan, sedangkan perlakuan penambahan ekstrak kunyit dan interaksi penambahan sorbitol dan ekstrak kunyit tidak berpengaruh nyata.

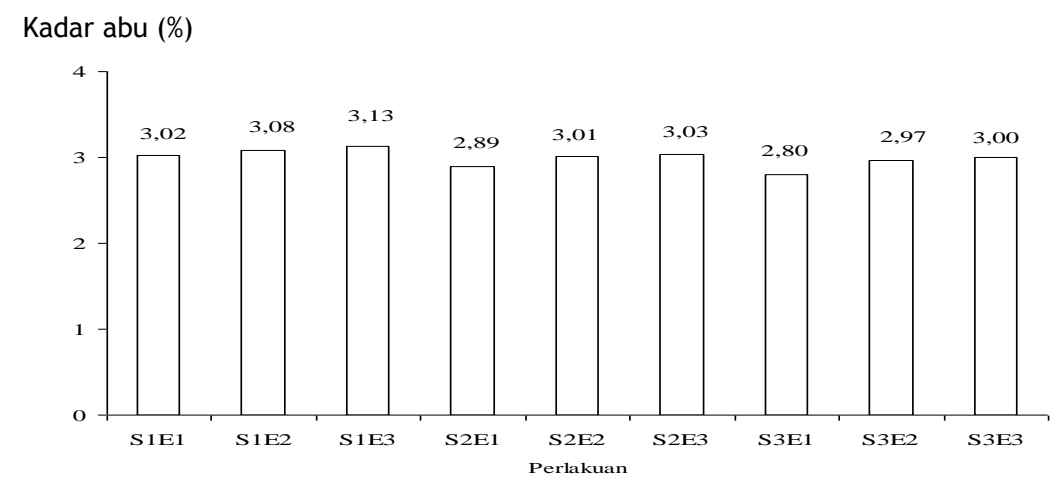

Gambar 2. Grafik rerata kadar abu (\%) permen jelly timun suri

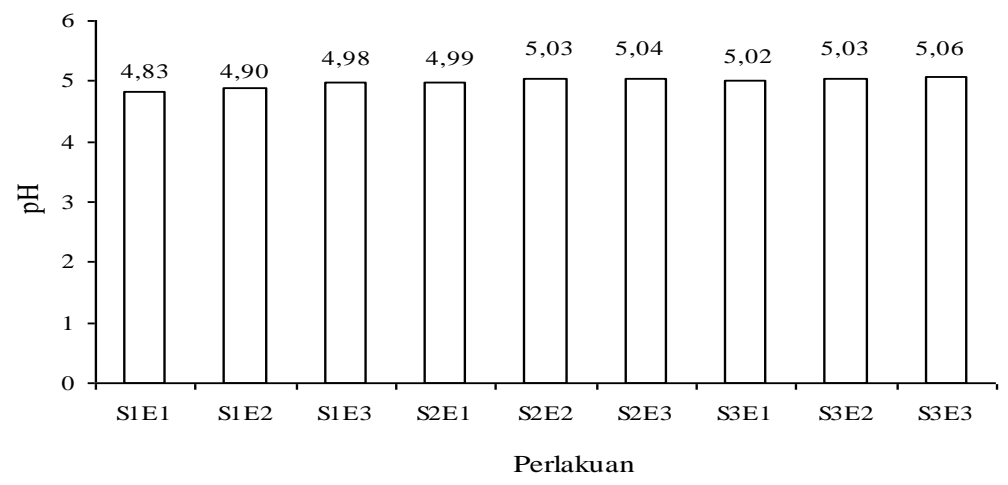

Gambar 3. Grafik rerata pH permen jelly timun suri 
Dalam pengolahan permen jelly timun suri, diberikan tambahan asam sitrat sehingga kondisi menjadi asam. Nilai pH larutan dapat mempengaruhi dalam pembentukan gel. Pembentukan gel optimum pada $\mathrm{pH} 4$ sampai 7 (Winarno, 1997). Proses pengolahan permen jelly timun suri ini akan membentuk ion-ion $\mathrm{H}^{+}$. Penggunaan sorbitol dengan konsentrasi yang tinggi cenderung menurunkan ion $\mathrm{H}^{+}$pada permen jelly timun suri yang dihasilkan. Hal ini dikarenakan sorbitol memiliki sifat yang sama dengan sifat fruktosa atau gula. Fruktosa memiliki sifat mampu mengikat ion-ion $\mathrm{H}^{+}$pada larutan (Winarno, 1997). Sehingga dengan penggunaan sorbitol yang makin banyak (23\%), ion $\mathrm{H}^{+}$yang terikat juga makin banyak dan menyebabkan nilai $\mathrm{pH}$ meningkat.

\section{Kadar Gula Total}

Analisa hasil pengamatan menunjukkan bahwa kadar gula total permen jelly timun suri yang diperoleh berkisar antara $32.23 \%$ sampai 40.83\%. Berdasarkan SNI 01-3547-1994 permen jelly, kandungan gula total dalam bahan berkisar minimal $30 \%$. Rerata kadar gula total permen jelly timun suri pada berbagai kombinasi perlakuan dapat dilihat pada Gambar 4.

Kadar gula total permen jelly timun suri tertinggi yaitu $40.83 \%$ diperoleh dari perlakuan konsentrasi $\mathrm{S}_{3} \mathrm{E}_{1}$ (sorbitol 23\% dan ekstrak kunyit $5 \%$ ), sedangkan kadar gula total terendah yaitu $36.50 \%$ dari perlakuan $\mathrm{S}_{1} \mathrm{E}_{3}$ (sorbitol $9 \%$ dan ekstrak kunyit 9\%). Hasil tersebut menunjukkan bahwa semakin besar konsentrasi sor- bitol (23\%) dan semakin kecil konsentrasi ekstrak kunyit $(5 \%)$ yang ditambahkan, maka kandungan gula total dalam bahan akan semakin meningkat.

Hasil analisa keragaman menunjukkan bahwa perlakuan konsentrasi sorbitol berpengaruh nyata terhadap nilai gula total permen jelly, sedangkan perlakuan konsentrasi ekstrak kunyit dan interaksi sorbitol dan ekstrak kunyit berpengaruh tidak nyata.

Penggunaan sorbitol pada pembuatan permen jelly timun suri yang semakin banyak (23\%) akan meningkatkan kandungan gula total dalam bahan. Sorbitol adalah jenis gula alkohol yang memiliki enam atom karbon dan merupakan bentuk tereduksi dari fruktosa (Anonim, 2008). Hal ini dikarenakan sorbitol memiliki fungsi yang sama dengan gula jenis lainnya yaitu memberi rasa manis, hanya saja tingkat kemanisan sorbitol $60 \%$ bila dibandingkan dengan sukrosa. Kadar gula total akan berhubung an dan memberikan pengaruh pada kadar air, tekstur, pH dan kadar asam total dalam bahan.

\section{Aktivitas Antioksidan}

Analisa ini dilakukan untuk mengetahui aktivitas antioksidan pada permen jelly timun suri yang dihasilkan. Aktivitas antioksidan yang diperoleh dari hasil pengamatan adalah berkisar antara $18.25 \%$ sampai $40.73 \%$. Rerata aktivitas antioksidan permen jelly timun suri yang dihasilkan dapat dilihat pada Gambar 5.

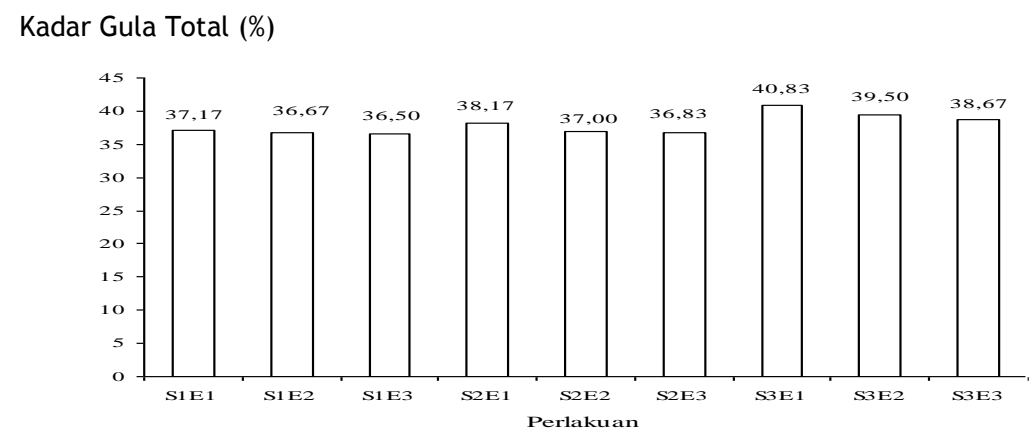

Gambar 4. Grafik rerata kadar gula total (\%) permen jelly timun suri

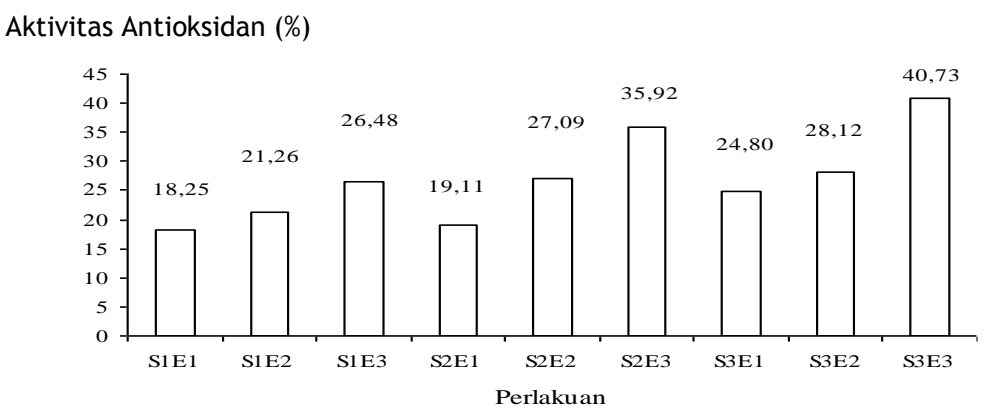

Gambar 5. Grafik rerata aktivitas antioksidan (\%) permen jelly timun suri 
Hasil pengamatan aktivitas antioksidan permen jelly tertinggi diperoleh dari perlakuan $\mathrm{S}_{3} \mathrm{E}_{3}$ yaitu $40.73 \%$ (sorbitol 23\% dan ekstrak kunyit $9 \%$ ), sedangkan aktivitas antioksidan terendah diperoleh dari perlakuan $\mathrm{S}_{1} \mathrm{E}_{1}$ yaitu $18.25 \%$. Hal ini menunjukkan bahwa semakin besar konsentrasi sorbitol (23\%) dan ekstrak kunyit $(9 \%)$ yang digunakan, maka semakin tinggi kandungan antioksidan dalam bahan.

Hasil analisa keragaman menunjukkan bahwa perlakuan konsentrasi sorbitol dan ekstrak kunyit, serta interaksi penambahan sorbitol dan ekstrak kunyit memberikan pengaruh nyata terhadap aktivitas antioksidan permen jelly yang dihasilkan.

Penambahan sorbitol yang lebih banyak (23\%) akan meningkatkan aktivitas antioksidan dalam bahan, karena kemampuan dari sorbitol sebagai humektan yang dapat mengikat air dalam bahan, sehingga air tidak bisa diuapkan selama pemanasan dan meminimalisir kehilangan zat gizi khususnya antioksidan kunyit selama pemasakan. Sorbitol selain berfungsi sebagai humektan dalam bahan dalam menjaga stabilitas kelembapan bahan, juga dapat melindungi komponen-komponen yang terikat kuat dalam bahan (Jakson, 1995).

Penggunaan ekstrak kunyit yang relatif banyak $(9 \%)$ akan memberikan kandungan antioksidan lebih tinggi dalam permen jelly timun suri yang dihasilkan. Menurut Trully et al. (2006), kandungan aktivitas antioksidan pada kunyit dihitung berdasarkan jumlah kandungan kurkumin, dan rata-rata kandungan kurkumin rimpang kunyit segar berkisar 50 sampai $60 \%$.

Hasil uji lanjut BNJ menunjukkan penambahan sorbitol dan ekstrak kunyit yang semakin tinggi akan meningkatkan aktivitas antioksidan pada pembuatan permen jelly timun suri yang dihasilkan. Hal ini dapat terjadi karena masing-masing bahan merupakan zat atau senyawa yang memiliki kadar atau aktivitas antioksidan yang tinggi dari senyawa yang dikandungnya.

\section{Uji Hedonik}

\section{Warna}

Hasil uji kesukaan Friedman-Conover terhadap warna permen jelly timun suri menunjukkan tingkat kesukaan panelis berkisar antara 2.76 sampai 3.12 (suka). Tingkat kesuka an terbesar terdapat pada perlakuan $\mathrm{S}_{2} \mathrm{E}_{3}$ (sorbitol $16 \%$ dan ekstrak kunyit $9 \%$ ), sedangkan tingkat kesukaan terkecil terdapat pada perlakuan $\mathrm{S}_{1} \mathrm{E}_{1}$ (sorbitol $9 \%$ dan ekstrak kunyit $5 \%$ ).
Penggunaan sorbitol dapat menyebabkan produk menjadi bening, karena sorbitol merupakan jenis gula alkohol yang sifatnya dapat bertahan pada temperatur tinggi dan tidak ikut bereaksi dalam reaksi Maillard (kecoklatan) (Soeratri et al, 2004). Konsentrasi sorbitol yang semakin tinggi (23\%) akan menjadikan tingkat kecerahan produk semakin tinggi.

Kunyit merupakan jenis tanaman yang memiliki banyak kandungan senyawa fitokimia yang baik untuk kesehatan, seperti kurkumin yang menghasilkan warna kuning (Wahyuni et al, 2004). Penambahan ekstrak kunyit pada pembuatan permen jelly timun suri dapat memperbaiki warna produk agar menjadi menarik selain dapat memberikan efek kesehatan. Faktor lain yang kemungkinan juga dapat mempengaruhi warna permen jelly yang dihasilkan, misalnya HFS dan buah timun suri. Buah timun suri mengandung provitamin A atau $B$-karoten yang mengandung pigmen warna kuning secara alami yang bersifat fitokimia bagi tubuh. Menurut Anonim (2006), penggunaan HFS pada proses pengolahan permen jelly yaitu untuk menghasilkan kecermelangan warna yang lebih baik.

\section{Tekstur}

Tekstur permen jelly berhubungan dengan keras dan lembut atau tingkat kekenyalan produk yang dihasilkan. Tekstur permen jelly yang dihasilkan dipengaruhi oleh beberapa faktor, yaitu kadar air, konsentrasi gula dan $\mathrm{pH}$. Kadar air yang tinggi pada produk akan mempengaruhi tekstur menjadi lembut. Hasil uji kesukaan Friedman-Conover terhadap tekstur permen jelly timun suri menunjukkan tingkat kesukaan panelis berkisar antara 2.40 (sorbitol (23\% dan ekstrak kunyit $9 \%$ ) sampai 3.08 (sorbitol $16 \%$ dan ekstrak kunyit 5\%) atau menunjukkan tidak suka sampai suka.

Hasil pengujian hedonik kepada panelis menunjukkan nilai terendah pada perlakuan $\mathrm{S}_{3} \mathrm{E}_{3}$ (sorbitol 23\% dan ekstrak kunyit 9\%). Hal ini berarti bahwa panelis tidak menyukai permen jelly yang lembut. Tekstur yang lembut pada permen jelly timun suri disebabkan oleh kandungan air dalam bahan sangat tinggi. Kandungan air dalam bahan sangat tinggi karena sifat dari gula alkohol sorbitol sebagai media pengikat air atau humektan.

\section{Aroma}

Menurut Soekarto dan Hubeis (2000), aroma pada makanan merupakan salah satu faktor yang menentukan kelezatan makanan yang berkaitan dengan indera penciuman. 
Hasil uji kesukaan Friedman-Conover terhadap aroma permen jelly timun suri menunjukkan tingkat kesukaan panelis berkisar antara 2.40 sampai 3.00 (tidak suka sampai suka). Tingkat kesukaan terbesar pada perlakuan kombinasi $\mathrm{S}_{2} \mathrm{E}_{1}$ (sorbitol $16 \%$ dan ekstrak kunyit $5 \%$ ), sedangkan tingkat kesukaan terkecil pada perlakuan $\mathrm{S}_{3} \mathrm{E}_{3}$ (sorbitol $23 \%$ dan ekstrak kunyit $9 \%$ ).

Analisa hasil pengujian hedonik kepada panelis menunjukkan nilai terendah pada perlakuan $\mathrm{S}_{3} \mathrm{E}_{3}$ (sorbitol 23\% dan ekstrak kunyit 9\%). Hal ini berarti bahwa panelis tidak menyukai permen jelly yang menggunakan konsentrasi sorbitol dan ekstrak kunyit yang terlalu tinggi. Aroma khas dari kunyit berpengaruh terhadap hasil sensoris, dengan konsentrasi tinggi maka aroma kunyit akan semakin terasa. Minyak turmerin merupakan jenis minyak atsiri pada kunyit yang memberi aroma harum dan rasa khas.

\section{Rasa}

Penilaian panelis terhadap rasa diartikan sebagai daya terima terhadap cita rasa atau flavour yang dihasilkan pada formulasi bahan yang digunakan. Hasil uji kesukaan FriedmanConover terhadap rasa permen jelly timun suri berkisar antara 2.44 sampai 3.08 (tidak suka sampai suka). Skor tertinggi diperoleh pada perlakuan $\mathrm{S}_{2} \mathrm{E}_{1}$ (sorbitol $16 \%$ dan ekstrak kunyit $5 \%$ ), sedangkan skor terendah pada perlakuan $\mathrm{S}_{3} \mathrm{E}_{3}$ (sorbitol 23\% dan ekstrak kunyit 9\%).

Penggunaan sorbitol yang tinggi (23\%) akan menyebabkan rasa permen terlalu manis dan penggunaan ekstrak kunyit dengan konsentrasi yang tinggi $(9 \%)$ menyebabkan rasa permen agak sedikit pahit, sehingga mempengaruhi tingkat kesukaan rasa permen jelly oleh panelis. Kunyit mengandung minyak atsiri jenis minyak turmerin yang memberikan aroma harum dan rasa khas pahit pada kunyit.

\section{KESIMPULAN}

Penambahan sorbitol berpengaruh nyata terhadap nilai kadar air, $\mathrm{pH}$, kadar gula total dan aktivitas antioksidan, sedangkan penambahan ekstrak kunyit berpengaruh nyata terhadap kadar air, dan aktivitas antioksidan permen jelly timun suri. Interaksi penambahan sorbitol dan ekstrak kunyit berpengaruh nyata terhadap aktivitas antioksidan permen jelly timun suri yang dihasilkan.

Sifat kimia dan organoleptik permen jelly timun suri terbaik diperoleh pada perlakuan $\mathrm{S}_{2} \mathrm{E}_{2}$ (sorbitol $16 \%$ dan ekstrak kunyit $7 \%$ ) de- ngan sifat kimia (kadar air 36.48\%, kadar abu $3.01 \%$, pH 5.03, kadar gula total $37 \%$ dan aktivitas antioksidan $27.09 \%$ ), dan sifat sensoris dengan skor kesukaan (warna 3.08, tekstur 2.88 , aroma 2.88 dan rasa 3.08 ).

\section{DAFTAR PUSTAKA}

Anonim. 2008. Mengenal Sorbitol. [terhubung berkala]. www.vanillamist.com. [September 2009].

AOAC. 1995. Official Methods od An Anlysis of Analysis Chemistry. Washington DC, United Stated of America.

Badan Pengawas Obat dan Makanan. 2001. Pemberlakuan Kode Makanan Indonesia. No HK. 00.05.5.00617. Jakarta.

Badan Standarisasi Nasional. 2004. Bahan Tambahan Pangan Pemanis Buatan, Persyaratan Penggunaan dalam Produk Pangan. SNI No. 01-6993-2004.

Balai Besar Penelitian dan Pengembangan Pasca panen Pertanian. 2004. Gula singkong dapat diproduksi di Pedesaan. [terhubung berkala]. http//www. Bb-pasca panen@litbang.deptan.go.id. [26 Oktober 2009].

Hayati A, Lidiasari E, \& Parwiyanti. 2008. Karakteristik Timun Suri. Laporan Penelitian Program PHK A2. Universitas Sriwijaya, Indralaya.

Jackson EB. 1995. Sugar Confectionory Manufacture, Second Edition. Cambridge University Press, Cambridge.

Jaswir I. 2007. Memahami Gelatin. Artikel Iptek. [terhubung berkala]. Http//www. duniapangankita.file.wordpress.com/gel atin.pdf. [6 September 2008].

Joyeux M, Lobstein A, \& Matier F. 1995. Comparative Antilipoperoxidant, Antinecrotic and Scavenging Properties of Terpenes and Biflavonesfrom Ginko and Some Falvonoids. Plant Medica, 61, 126-129.

Soekarto TS \& Hubeis M. 2000. Metodologi Penelitian Organoleptik. Institut Pertanian Bogor, Bogor.

Soerarti W, Rasita N, \& Himawati ER. 2004. Pengaruh Jenis Humektan Terhadap Pe- 
lepasan Asam Sitrat dari Basis Gel Secara In Vitro. http://www. Wikipedia.org. [20 April 2010].

Sudarmadji S, Haryono B, \& Suhardi. 1997. Prosedur Analisa untuk Bahan Makanan dan Pertanian. Penerbit Liberty, Yogyakarta.

Sulaeman A \& Katipana NGF. 1997. Pengaruh Pemberian Minuman Kunyit Terhadap Kadar Kolesterol Serum Tikus. Pusat Penelitian Gizi Masyarakat dan Sumberdaya Keluarga, FAPERTA, IPB, Bogor.

Sura OM, Pambayun R, \& Lidiasari E. 2009. Karekteristik Permen Jelly Timun Suri (Cucumis melo L.) Pada Berbagai Konsentrasi Gelatin Dan HFS. Makalah Seminar Mahasiswa. Universitas Sriwijaya, Indralaya.
Trully MS, Parinussa, \& Timotius KH. 2006. Pengaruh Penambahan Asam Terhadap Aktivitas Antioksidan Kurkumin. Magister Biologi, Universitas Kristen Satya Wecana, Salahtiga.

Usmiati S \& Yuliani S. 2004. Pemanis Alami dan Buatan untuk Kesehatan. Warta Penelitian dan Pengembangan Tanaman Industri 10(1): $13-17$

Wahyuni A, Hardjono, \& Yamrewav PH. 2004. Ekstraksi Kurkumin Dari Kunyit. Pros. Seminar Nasional Rekayasa Kimia dan Proses 2004. Jurusan Teknik Kimia, Universitas Diponogoro, Semarang. hlm. 2.

Winarno FG. 1997. Kimia Pangan dan Gizi. Gramedia Pustaka Utama, Jakarta.

Winarto WP. 2005. Khasiat dan Manfaat Kunyit. Agromedia Pustaka, Jakarta. 